Portland State University

PDXScholar

8-23-1974

\title{
A study of RNA bacteriophage 7s infection of Pseudomonas aeruginosa
}

Deanne Benson

Portland State University

Follow this and additional works at: https://pdxscholar.library.pdx.edu/open_access_etds

Part of the Biochemistry Commons, and the Biology Commons

Let us know how access to this document benefits you.

\section{Recommended Citation}

Benson, Deanne, "A study of RNA bacteriophage 7s infection of Pseudomonas aeruginosa" (1974). Dissertations and Theses. Paper 2141.

https://doi.org/10.15760/etd.2139

This Thesis is brought to you for free and open access. It has been accepted for inclusion in Dissertations and Theses by an authorized administrator of PDXScholar. Please contact us if we can make this document more accessible: pdxscholar@pdx.edu. 
AN AUSTRACS OF THE IFESIS OF Deanne Benson for the Master of Science in Biology presented 23 August 1974.

Title: A Study of RNA Bacteriophage $7 \mathrm{~s}$ infection of Fseudcinonas aeruginosa

APPROVED RY MEMEERS OT THE THESIS COMMITTEE:

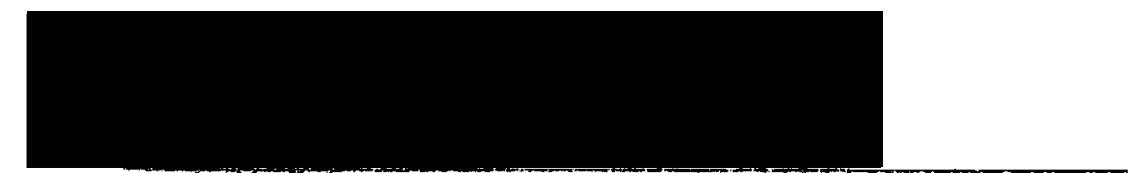

EarT Fisher, Jr., Chairman

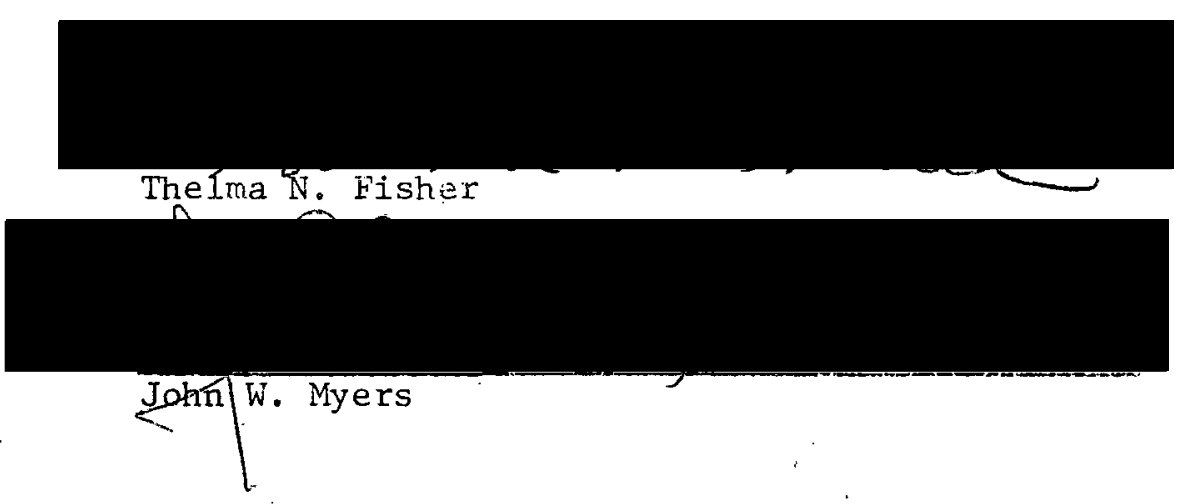

A study was conducted to find the effect of magnesium, calcium, thangarest and zirie ions on the infection of Pseveomonas aeruginosa strain 10 by the FNA bacteriophage 73. When an 18 hour progeny experiment was performed, it was found that magnesium, calcium and manganese had different effects on bacteriophage production and was dependent on the bacterial growth conditions. RNA bacteriophage is progeny production was significantiy enhanced by the addition of magnesium to cultures of Pseudomonas aeruginosa $1 \mathrm{C}$ grown in a magnesium deficient medium. Under these environtenal conditions there was a slight increase in progeny in the presence of caicium. When Pseudomonas aeruginosa ic was grown it a complete medium, the infection of cells by bacteriophage $7 s$ was enhanced by magnesium and calcium but not manganese or zinc, as demonstrated by the One Step Growth Curve. 
A STUDY OF RNA BACTERIOPHAGE 7S INFECTION

OF Pseudomonas aeruginosa

$$
\text { by }
$$

DEANNE BENSON

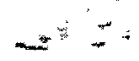

A thesis submitted in partial fulfillment of the requirements for the degree of

\section{MASTER OF SCIENCE}

in

BIOLOGY

Portland State University. 1974 
TO THE OFFICE OF GRADUATE STUDIES AND RESEARCH:

The members of the Committee approve the thesis of

Deanne Benson presented 23 August 1974.

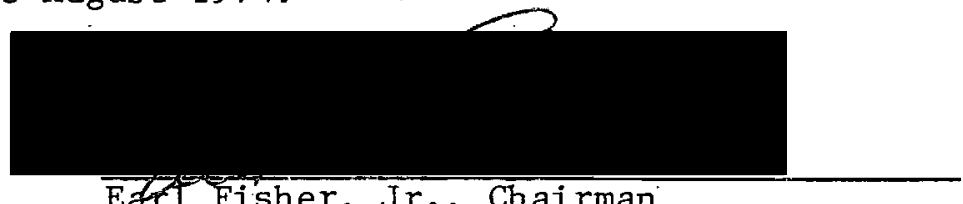

EdrI Fisher, Jr., Chairman

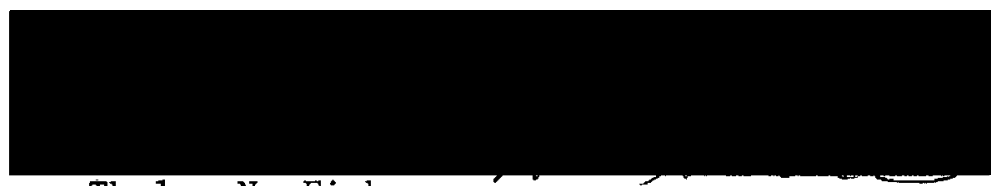

Thelma N. Fisher

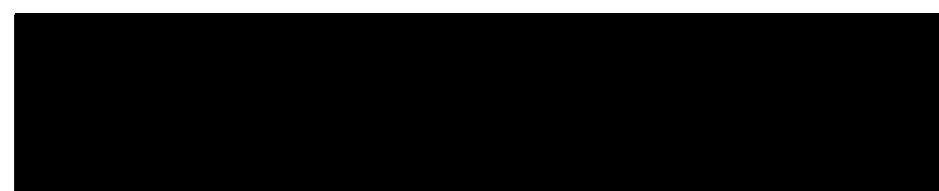

Johntw. Myers

\section{T}

APPROVED:

Earl Fisher, Jr., Head, Department of Biology

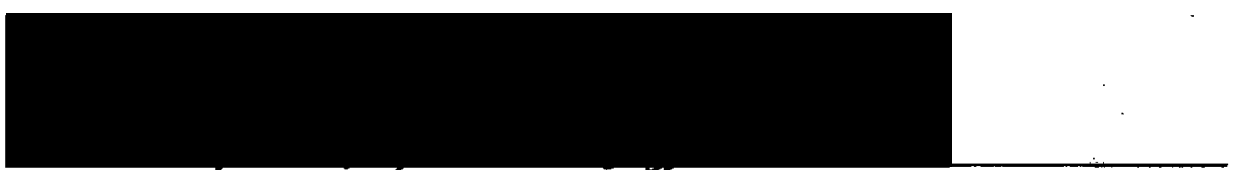

David T. Clark, Dean of Graduate Studies 


\section{ACKNOWLEDGEIENT}

I wish to thank all facuity and staff members of the Portland State University Department of Biology, for making this project possible. Appreciation is extended to Dr. Earl Fisher, Head of the Department of Biology and advisor to this project; Dr. Thelma Fisher for her help in editing the manuscript; special thanks and recognition to Dr. John Myers for his scientific advice in this project. 
ACKNOWLEDGEMENT ........................... . . . . .

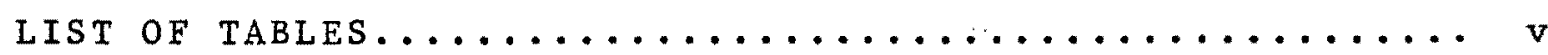

LIST OF FIGURES......................... vi

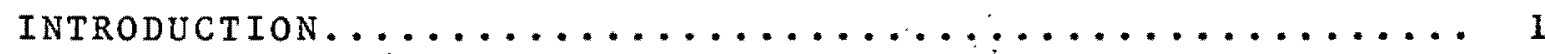

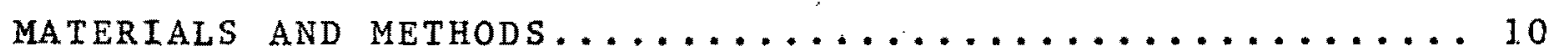

Bacteria and Bacteriophage.................. 10

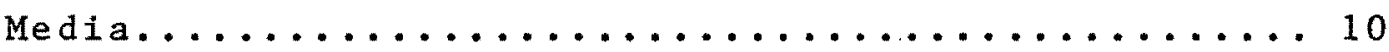

Chemicals............................ 10

Equipment...........................

Assay................................ 11

7s Bacteriophage Stock Preparations............. 11

Viable cell Counts of Pseudomonas aeruginosa

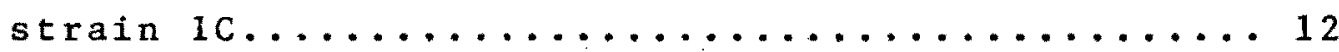

Bacteriophage $7 \mathrm{~s}$ Production Using Divalent Cations. 12

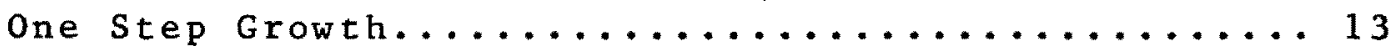

One Step Growth Curve Variations.............. 14

Stability of Phage $7 s$ in Divalent Cations........ 14

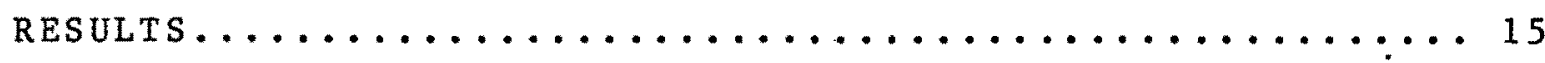

Pseudomonas aeruginosa strain lC Viable Counts.... 15

Bacteriophage $7 \mathrm{~s}$ Production in the Presence of

Various Concentrations of Divalent Cations..... 15

One Step Growth Curve..................... 20

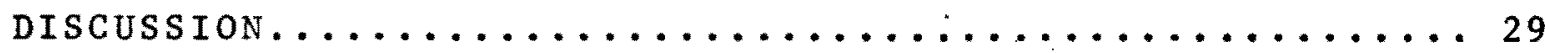

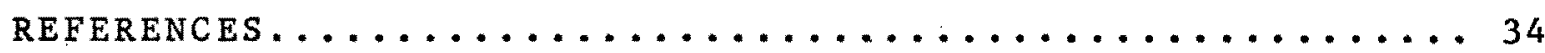




\section{LIST OF TABLES}

TABLE

PAGE

I Bacteriophage $7 \mathrm{~s}$ Production in the Presence of

1 mM Concentrations of Divalent Cations........ 17

I Production of Phage 7s: A System Containing

$0.1 \mathrm{mM}$ Magnesium and Various Concentrations of

a second cation........................... 19

II Production of Phage $7 \mathrm{~s}$ with Addion of 1 mM

Cations at infection Time................. 23 


\section{LIST OF FIGURES}

FIGURE

PAGE

1 Viable Count of Pseudomonas aeruginosa strain $1 C$ in complete $F$ Medium and F Medium Magnesium Free............................. 16

2 Bacteriophage $7 \mathrm{~s}$ Production in the Presence of Magnesium Concentrations................. 18

3 One Step Growth Experiment with Pseudomonas

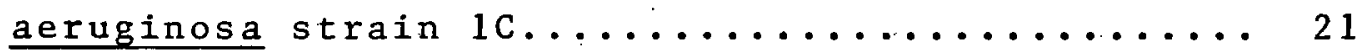

4 One Step Growth Experiment with Pseudomonas aeruginosa strain 1 ..................... 24

5 Stability of Free Bacteriophage $7 \mathrm{~s}$ in F Medium Containing Various Concentrations of Divalent .

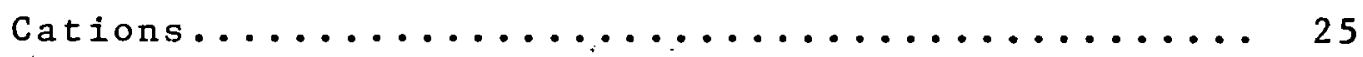

6 One Step Growth Experiment with Pseudomonas aeruginosa strain 1 c................... 27 


\section{INTRODUCTION}

In 1961 Loeb and Zinder (19) isolated a bacteriophage that contained ribonucleic acid (RNA) as its genetic material. This was a significant biological find, since previous to this time only deoxyribonucleic acid (DNA) bacteriophages had been isolated and characterized.

Aside from the unique feature of containing RNA for genetic material, the E. coli RNA phages had a second feature which, before 1961, had not been described. The E. coli RNA bacteriophages were found to infect only cultures containing $\mathrm{Hfr}$ and $\mathrm{F}^{+}$genetic donor cells (8). Thus, they exhibited strain specificity.

Electron micrographs by Ċrawford and Gestland (9) helped to explain how Hfr and $\mathrm{F}^{+}$cells were infected by RNA bacteriophage R17. This phage had an affinity for the sex pili of E. coli donor cells, but no apparent affinity for the pili of nondonor cells. In conjugating mixtures of $\mathrm{Hfr}$ and $F^{-}$cells, the phage were laterally alined along the $F$ pilus of only one of the mating partners. The $F$ pilus is under the genetic control of the F episome in E. coli donor strains (8). In 1963 Feary, Fisher and Fisher (14) isolated an RNA bacteriophage, 7s, from a multilysogenic strain of Pseudomonas aeruginosa strain 7. Bacteriophage $7 \mathrm{~s}$ was found in the supernatent of overnight broth cultures of Pseudomonas aeruginosa strain 7. This implied that phage $7 \mathrm{~s}$ was associated with strain 7 in a lysogenic state. Further evidence for some type of a carrier state was provided by the immunity of Pseudomonas aeruginosa strain 7 to phage $7 \mathrm{~s}$ infection. Also, phage 7s was associated with strain 7 in two year old lyophilized preparations. 
Several strains of Pseudomonas aeruginosa were sensitive to phage $7 s$ with strain 1 being the most sensitive. Pseudomonas aeruginosa strain 1 also supported the production of RNA bacteriophage PP7, which was isolated from sewage. The two phages were shown by Bradley (3) to be related serologically by their cross sensitivity to the two respective antisera.

Electron micrographs $(3,18)$ show that in the infection of Pseudomonas aeruginosa, the bacteriophages PP7 and 75 also use the pilus as an attachment organelle. In this case the attachment appears to occur only on the polar pili.

If the host-phage complex of Pseudomonas aeruginosa strain 1 and phage PP7 were similar to the E. coli system, one would expect PP7 and $7 \mathrm{~s}$ to be donor specific. But Bradley (3) found that phage PP7 was equally infective for both $\mathrm{FP}^{+}$donor and $\mathrm{FP}^{-}$nondonor cells of Pseudomonas aeruginosa.

The RNA bacteriophage study presented in this thesis is concerned with the requirement for a divalent cation for infection, since virus infection generally requires a divalent cation, either for adsorption onto the host cell or for injection of nucleic acid into the host cell.

The adsorption of virus to cell was investigated by Puck and Garen (25). Their data were obtained from adsorption experiments with mono and divalent ions.

The DNA bacteriophage $T_{1}$, would not adsorb to host $\underline{E}$. coli when distilled water was the adsorption medium. There"was adsorption when the phage-host mixture was put into a buffered solution containing elther $\mathrm{Na}^{+}, \mathrm{K}^{+}, \mathrm{Li}^{+}, \mathrm{NH}_{4}^{+}, \mathrm{Ca}^{++}, \mathrm{Ni}^{++}$or $\mathrm{Mn}{ }^{++}$. Divalent ions were 
more efficient for adsorption in those cases where monovalent ions supported adsorption. Puck and Garen speculated that two monovalent ions were utilized in place of one divalent ion. They hypothesized that the cations were used to bring the negatively charged surfaces of cel1 and virus together for an electrostatic attachment. At high ion concentrations there was an inhibition of adsorption. This inhibition was explained as a repulsion of charges when the ionic strength was sufficient to bind to both surfaces. At lower ionic strengths the ions would bind to only one surface for an electrostatic attachment of negatively and positively . charged surfaces.

The hypothesis of Puck and Garen was found to agree with data presented by Danziger and Paranchych (11) for RNA bacteriophage R17. Complexes of free E. coli pili and R17 phage didnot form in the presence of only tris buffer. However, free pili-phage complexes were formed in the presence of tris buffer with one of the monovalent ions $\mathrm{K}^{+}, \mathrm{Na}^{+}$or $\mathrm{NH}_{4}^{+}$or one of the divalent ions $\mathrm{Mg}^{++}, \mathrm{Ca}^{++}, \mathrm{Ni}^{++}$or $\mathrm{Mn}^{++}$. When the adsorption of phage R17 to free pili was plotted against the ionic strength of mono and divalent lons, it was found that with increasing. ionic strength there was increasing adsorption to a maximum ionic strength of 0.1 .

Valentine (28) presented a hypothesis for the extracellular stages of infection by RNA bacteriophages, using phage +2 as a model. These stages were: adsorption to pili, discussed above, injection, transport and penetration of RNA.

Loeb and Zinder found that a culture of.E. coli did not become Infected with phage $\mathrm{f} 2$ if small quantities of RNase was added to the. 
medium at the time of infection.

The conditions of this RNase sensitivity in the presence of $\underline{E}$. coll has been a subject for extracellular infection studies. When free E. coli pili were mixed with phage f2 to form a pili-phage complex the viability of the phage was not affected by the addition of RNase. Also, there was no effect on free phage in the presence of RNAase.

The only known case where infective phage $f 2$ was included in a preparation of piliated E. coli cells and where no RNAase sensitivity was observed, was when the mixture was held at a temperature of $0 \mathrm{c}$. When the temperature of E. coli-phage $f 2$ complex was raised to $37 \mathrm{C}$, the phage became RNAase sensitive in 1.5 minutés (28). This RNAase sensitivity of phage $f 2$ required that the F-pili be attached to the cells in a $37 \mathrm{C}$ environment. for the stage Valentine termed the injection stage. Such properties of the injection stage hold only for E. coli RNA bacteriophages since phage $7 \mathrm{~s}$ of Pseudomonas aeruginosa is RNAase sensitive at all times, even when not in the presence of the cell (14).

Paranchych (24) discusses the RNAase sensitive stage in terms of eclipsing of phage infectivity. During this five minute, eclipse period the RNA of phage $R 17$ remains associated with the cell as the phage capsid is desorbed into the medium. This eclipsing process like the RNAase sensitivity is temperature dependent. The dependency of eclipsing on temperature suggest that this is an energy requiring stage. An indirect method of noting energy requirements of the RNA phage eclipse stage would be to inhibit the energy production of the host ce11. This was accomplished (10) when $\underline{E}$. coli was placed in an anaerobic situation in order to inhibit the oxidation of pyruvate and 
therefore energy production. 'Cells were infected with bacteriophage R17 under anaerobic conditions. The assay for R17 provided evidence that there was a $72 \%$ reduction in plaque forming units (PFU) which was considered the result of a reduction of available cellular energy (10).

A more direct approach to study energy needs for eclipsing was done by measuring an actual change in the level of ATP during infection (24). A decrease in 32P labeled ATP began immediately after infection and lasted five minutes, an interval which coincided with the time period of the eclipse stage. An interesting aspect of this study was the effect of phage concentration "on the utilization of ATP. When low levels of phage multiplicities were used, there was very little decrease in the ATP levels. The loss of ATP with low phage multiplicity was quickly restored to its preinfection level. When higher phage to cell ratios were used there was a larger reduction of.ATP levels. With this larger reduction of ATP there was little restoration to preinfection levels: This proportional pattern of ATP reduction with the multiplicity of infection was seen even above the maximum level of phage penetration.

From the above data, it appeared, that the five minute interval of RNA phage infection was detected by observing sensitivity to RNAase, temperature dependence and the necessity for cellular energy.

In this five minute period the coat was separated from the ribonucleic acid after which the coat was eluted into the medium. Following coat elution, viral RNA and the "A" protein (one of 3 proteins coded for by the phage genome) remained attached to the pilus. The "A" protein 
was cleaved into three components (16) before phage RNA penetrated the cel1. Two of the three cleavage products entered the cell with the ribonucleic acid.

The third stage of Valentine's hypothesis of extracellular infection concerned transport of ribonucleic acid through the lumen of the pilus. Evidence to support the Conduction Theory was given from experimental data using RNA bacteriophage f2 and DNA bacteriophage fl. Phage f2 adsorbed to the side of the E. coli F pilus, whereas $f 1$ filamentous DNA bacteriophage adsorbed to the tip of the pilus (27). In an E. coli culture Infected with both the RNA phage f2 and 32p labeled DNA phage $f 1$, only the unlabeled phage $f 2$-produced infective centers. Both RNA and DNA phages adsorbed to the pilus therefore the reason that DNA phage did not infect was not due to its inability to adsorb. This evidence was interpreted to mean that the lumen of the pili was blocked to the DNA of bacteriophage $f 1$.

The hypothesis of a retractable pilus was proposed as the second model of nucleic acid transport. The Retraction Model suggested that on contact with a bacteriophage, the pilus would retract, as a result of being depolymerized by a mechanism at its base (21).

Details of this model were extended by Bradley (4) who suggested that after adsorption perhaps the viral RNA was ejected onto the pilus. The adsorption of phage onto the pilus was thought to be a signal for depolymerization to begin. According to the model penetration of RNA into the cell was accomplished as depolymerization continued to take place at the base of the pilus.

Bradley suggested (5) that.retraction of the pilus stimulated 
production of new pili growth. Electron micrographs of uninfected Pseudomonas aeruginosa strain 1C cells were compared with cells infected with phage PP7. In total numbers of polar pili present in the system, the infected cells contained more pili than the uninfected celis. Correspondingly there was a 40-50\% decrease in the length of the RNA phage labeled pili. This shorter length of RNA phage labeled pili was taken as evidence to support the Retraction Theory.

A reduction of pili length was observed also on electron micrographs of bacteriophage R17 infected cells. Following the Conduction Mode1, Paranchych (24) predicted that the shortening of pili was due to fragmentation. To determine if pili were fragmented at the time of infection, phage attachment ability of the supernatant fluid was measured. Following infection there was an increase of ${ }^{14} \mathrm{C}$ labeled phage attached to free p1li in supernatant fluid preparations.

Penetration of RNA Into the host cell was considered the last stage in the extracellular infection process as proposed by Valentine. Paranchych (22) has shown by the One Step Intracellular growth curve and by a 100 min infection experiment that divalent cations were required for phage $\mathrm{R} 17$ infection of E. Coli. Infection by $\mathrm{R} 17$ was conducted In the absence of a divalent cation or with various concentrations of cations. He found a loss of plaque forming units (PFU) in the absence of divalent cations and in the presence of $\mathrm{Mn}^{++}, \mathrm{Zn}^{++}, \mathrm{Ni}^{++}$and $\mathrm{co}^{+}$. There was a slgnificant rise in phage titer in the presence of $\mathrm{Mg}^{++}, \mathrm{Ca}^{++}, \mathrm{Sr}^{++}$or $\mathrm{Ba}^{++}$. Another phage adsorption experiment was carried out with $32 \mathrm{P}$ labeled phage $\mathrm{R} 17$ with and without magnesium. Two five $\mathrm{ml}$ aliquots were withdrawn at various times; one aliquot was washed 
repeatedly. The bacterial pellets from both samples were assayed for radioactivity. Radioactive phage were associated with the bacteria of the unwashed sample in the presence and absence of magnesium. The washed sample had radioactive phage associated with the bacterial cell only in the presence of magnesium. Paranchych concluded that $\mathrm{Mg}^{+}$, $\mathrm{Ca}^{+}, \mathrm{Ba}^{++}$and $\mathrm{Sr}^{++}$were used by. phage RI7 for cell penetration.

The actual function of divalent cations in penetration remains a mystery. Therefore, one can only. speculate on the need of cations. One concept is that an enzyme may facilitate penetration or it may be used in the depolymerization process, where divalent cations serve as cofactors.

Valentine hypothesized that the role of the divalent cations was to serve as an electrostatic force in the separation of RNA and capsid. However, Paranchych (22) demonstrated that separation of RNA from capsid took place before there was a divalent cation requirement; therefore it seemed probable that the function of divalent cations was to provide structural integrity of either the RNA or the pilus. Cations may be needed to stabilize infecting RNA in a conformation appropriate for penetration.

Finally, another hypothesis concerning the function of divalent cations in phage penetration, is that cations may change cell permeability. A change in permeability may make the cell more competent for RNA penetration. Divalent cations are known to make bacterial cells more permeable to free phage DNA (20) but this capacity has not been shown for free phage RNA. The permeability of $\underline{E}$. coli to free DNA, is aided by the addition of calcium in these systems. Up to this time a 
requirement for a specific divalent cation has not been shown for bacteriophage 7s infection of Pseudomonas aeruginosa. Therefore, the experimental problem presented in this thesis is to show whether or not divalent cations such as magnesium, calcium, manganese and zinc enhance Infection of Pseudomonas aeruginosa by the RNA bacteriophage 7s. 
Bacteria and Bacteriophage

Pseudomonas aeruginosa strain 1C (hereafter known as PS1C) and RNA bacteriophage $7 \mathrm{~s}$, were obtained from the collection of Dr. Ear1 Fisher, Jr. The bacterium PSIC was stored at $4 \mathrm{C}$ on Nutrient Broth Yeast Extract Agar (NBYE) plates and the phage $7 \mathrm{~s}$, was stored at $4 \mathrm{C}$ in $0.85 \%$ saline.

Media

NBYE 1iquid growth medium: Difco Yeast Extract in a concentration of $5 \mathrm{~g}$ per liter was added to nutrient broth for growth of the organism.

NBYE Agar Plates:- A solid medium essential for phage assays consisted of NBYE liquid medium containing $15 \mathrm{~g} / 1$ iter Difco Bacto-Agar. Plates were prepared to contain approximate1y $25 \mathrm{~m} 1$ of NBYE Agar medium per plate.

Soft Agar Tubes: Soft agar, consisting of. $0.9 \%$ agar dispensed in $4 \mathrm{~m} 1$ volumes was employed in the phage assay procedure.

F Medium (15): This medium contained Sodium Lactate $60 \%$ (Pfanstiek1 Laboratories, Inc.) $16 \mathrm{ml}, \mathrm{NH}_{4} \mathrm{Cl} 1 \mathrm{~g}, \mathrm{~K}_{2} \mathrm{HOP}_{4} 0.7 \mathrm{~g}, \mathrm{KH}_{2} \mathrm{PO}_{4}$ $0.3 \mathrm{~g}, \mathrm{Na}_{2} \mathrm{SO}_{4} 0.1 \mathrm{~g}, \mathrm{MgSO}_{4} \cdot 7 \mathrm{H}_{2} \mathrm{O} 0.1 \mathrm{~g}$, per 1iter of distilled water. All of the above salts were of analytical reagent grade.

F Medium ( $M$ g free): This medium was identical with the complete F Medium, except magnesium salts äre not added.

\section{Chemicals}

Analytical reagent grade salts $\left(\mathrm{ZnSO}_{4} \cdot 7 \mathrm{H}_{2} \mathrm{O}, \mathrm{MnSO}_{4} \cdot \mathrm{H}_{2} \mathrm{O}\right.$, 
$\mathrm{CaCl}^{2} \cdot 2 \mathrm{H}_{2} \mathrm{O}, \mathrm{MgSO}_{4} \cdot 7 \mathrm{H}_{2} \mathrm{O}$ ) were prepared and sterilized in the following concentration, $1 \mathrm{M}, 0.1 \mathrm{M}$ and $0.01 \mathrm{M}$.

Equipment

The Klett Summerson Photoelectric Colorimeter, Mode1 800-3, and number 42 and 66 filters were used for turbidmetric studies. The Sorval1 Superspeed RC2-B and Beckman Mode1 L2-65B U1tracentrifuge were required for sedimenting samples.

Assay

Bacteriophage assays were carried out by the Soft Agar Overlay Method as described by Adams (1). The bottom layer Soft Agar Overlay was used also for Pseudomonas aeruginosa viable cell counts.

\section{7s Bacteriophage Stock Preparations}

Bacteriophage $7 \mathrm{~s}$ was plated on a lawn of PS1C. Single plaques were picked and suspended in $1 \mathrm{ml}$ NBYE each. Exponentially growing cultures of PSIC were infected with the picked plaque suspensions, after which they were aerated at $37 \mathrm{C}$ for $18 \mathrm{hr}$. Suspensions were treated with $0.1 \mathrm{ml}$ chloroform to lyse infected cells.

Partial purification of the phage lysate was obtained by differiential centrifugation. Cellular debris was sedimented at 4,340 $\mathrm{g}$ for $20 \mathrm{~min}$. The supernatant fluid was centrifuged at $70,000 \mathrm{~g}$ for 120 min; pellets were resuspended in $10 \mathrm{ml}$ of $0.85 \%$ saline and centrifugation cycles were repeated. Final pellets were resuspended in $10 \mathrm{ml}$ of $0.85 \%$ saline for use as phage stock. The titer as assayed was $1.7 \times 10^{10}$ phage/m1. 
Viable Ce11 Counts of Pseudomonas aeruginosa strain 1C:

Two erlenmeyer flasks, one with $100 \mathrm{ml}$ of complete F Medium and the second with $100 \mathrm{ml}$ of magnesium free $\mathrm{F}$ Medium, were each inoculated with $1 \mathrm{ml}$ of a starter culture of the bacterium PSIC. Starter cultures were grown with and without magnesium for each respective test. Hourly samples containing $6 \mathrm{ml}$ were withdrawn from the flask. Turbidmetric readings of $5 \mathrm{ml}$ aliquots of $\mathrm{PS} 1 \mathrm{C}$ cultures were taken using the Klett \#66 filter. One $\mathrm{ml}$ of culture was placed in a dilution tube containing cold NBYE after which serial dilutions were carried out. Appropriate dilutions were assayed for viable counts by the Soft Agar Overlay Method.

\section{Bacteriophage 7s Production Using Divalent Cations}

In preparation of experimental test tubes, size $18 \times 150 \mathrm{~mm}$, appropriate concentrations of salts were added sterilely to each tube containing $10 \mathrm{ml}$ magnesium free $\mathrm{F}$ Medium.

Experimental tubes were infected with $0.8 \mathrm{ml}$ of a PSIC starter culture grown approximately $3 \mathrm{hr}$ in the absence of magnesium. The inoculum was held at $37 \mathrm{C}$ with aeration for $2 \mathrm{hr}$ or until growth had reached about 1 to $2 \times 10^{7}$ viable counts/m1 as determined by a standard of viable counts and Klett \#66 filter readings. At this time bacterium PSIC was infected with phage $7 \mathrm{~s}$, at a multiplicity of 1 phage infectious unit per bacterium. After an $18 \mathrm{hr}$ infection interval, where cultures were held at $37 \mathrm{C}$ under aerated conditions, infected cells were lysed with chloroform. Lysed cells and phage preparations were centrifuged at 4,340 $\mathrm{g}$ for $20 \mathrm{~min}$ and phage lysates were assayed for 
plaque forming units.

\section{One Step Growth}

Ten ml preparation of complete $F$ Medium were inoculated with $1 \mathrm{ml}$ of starter cultures of PSIC grown in F Medium containing magnesium. Inoculated cultures were returned to an aerated $37 \mathrm{C}$ environment, until there was a turbidity reading of 10 as measured using the Klett filter \#66. At this time cultures were divided into aliquots of $2 \mathrm{ml}$ each and centrifuged $20 \mathrm{~min}$ at $4,340 \mathrm{~g}$. Cells were resuspended in $2 \mathrm{ml}$ of magnesium free $F$ Medium. This procedure was repeated twice for washing purposes. Final-pellets were resuspended in $2 \mathrm{mi}$ of prewarmed $\mathrm{F}$ Medium (Mg free), or F Medium with $1, \mathrm{mM} \mathrm{MgSO}_{4}, \mathrm{CaCl}_{2}, \mathrm{MnSO}_{4}$ or $\mathrm{ZnSO}_{4}$, respectively. These tubes were held in a $37 \mathrm{C}$ water bath for a $5 \mathrm{~min}$ adsorption period, as in the Fowler and Cohen (15) procedure.

Tubes 1 through 5 were centrifuged at $4,340 \mathrm{~g}$ for $20 \mathrm{~min}$ in order to separate the bacterium-phage complex from unadsorbed phage. Supernatant fluids containing unadsorbed phage were held in ice for phage assay procedures conducted later, Infected bacterial pellets were resuspended in the same prewarmed media as that contained in the adsorption tubes. After 5 more minutes at $37 \mathrm{C}$ serial dilutions were made of bacterium-phage preparations in NBYE. P1aque forming units (PFU) were assayed from tubes 1 through 5 , by plating $0.1 \mathrm{ml}$ samples with a lawn of PS1C, by the Soft Agar Overlay Method. Assays were carried out at 10 minute intervals for 60 min. This routine was followed by an $80 \mathrm{~min}$ and a $120 \mathrm{~min}$ assay for phage $7 \mathrm{~s}$. 
One Step Growth Curve Variations

\#1. The procedure as detailed above was followed except, starter cultures were grown without magnesiun.

\#2. The procedure was the same as described above since the starter culture was grown in the presence of magnesium, however, the difference was that cells were grown to a higher density (approximately $5 \times 10^{8} \mathrm{cells} / \mathrm{ml}$ ) than mentioned earlier and centrifugation was carried out at $3,020 \mathrm{~g}$ for $10 \mathrm{~min}$.

\section{Stab1lity of Phage 7s in Divalent Cations}

Free phage $7 \mathrm{~s}$ preparations were incubated at $37 \mathrm{C}$ in magnesium free $F$ Medium in the presence of the appropriate divalent cation at a concentration of $1 \mathrm{mM}$. Bacteriophage suspensions were diluted and assayed at time zero, $1 \mathrm{hr}, 3 \mathrm{hr}$ and $18 \mathrm{hr}$ by the Soft Agar Overlay Method, using Pseudomonas aeruginosa as the bacterial lawn. 


\section{RESULTS}

Pseudomonas aeruginosa strain $1 \mathrm{C}$ Viable Counts

A minimal medium for growth was desired since the effect of divalent cations could be detected more easily. Viable counts of Pseudomonas aeruginosa strain $1 \mathrm{C}$ were assayed after growth in F media with $\left(4 \times 10^{-4} \mathrm{M}\right)$ and without $\mathrm{MgSO}_{4}$. Viable counts (Fig. 1) from cultures grown in the absence of magnesium were very low indicating there was little cell growth.

Bacteriophage 7s Production in the Presence of Various Concentrations of Divalent Cations

Magnesium and calcium were shown to enhance bacteriophage $7 \mathrm{~s}$ titers over that of input phage inoculum of $1.7 \times 10^{7}$ particles $/ \mathrm{m} 1$. Lysates of cultures containing manganese indicated a decrease in plaque forming units (PFU). While those grown in the presence of zinc appeared to remain constant. It was not possible to tell if the titers shown in Table I were from the effects of the cations or from an indirect result of magnesium starvation of the host cel1.

The effect of various concentrations of magnesium ions on phage 7s infection of Pseudomonas aeruginosa are shown in Figure 2. The optimum magnesium concentration for this system is $1 \mathrm{mM}$ magnesium. The possibility that the results plotted in Figure 2 are due to cellular effects has not been investigated.

Since magnesium was found to be beneficial for growth of pseudomonas and to enhance $7 \mathrm{~s}$ phage infection, magnesium was used in combination with calcium, manganese and zinc (Table II) to determine related effects on viral multiplication. The concentration of 
16

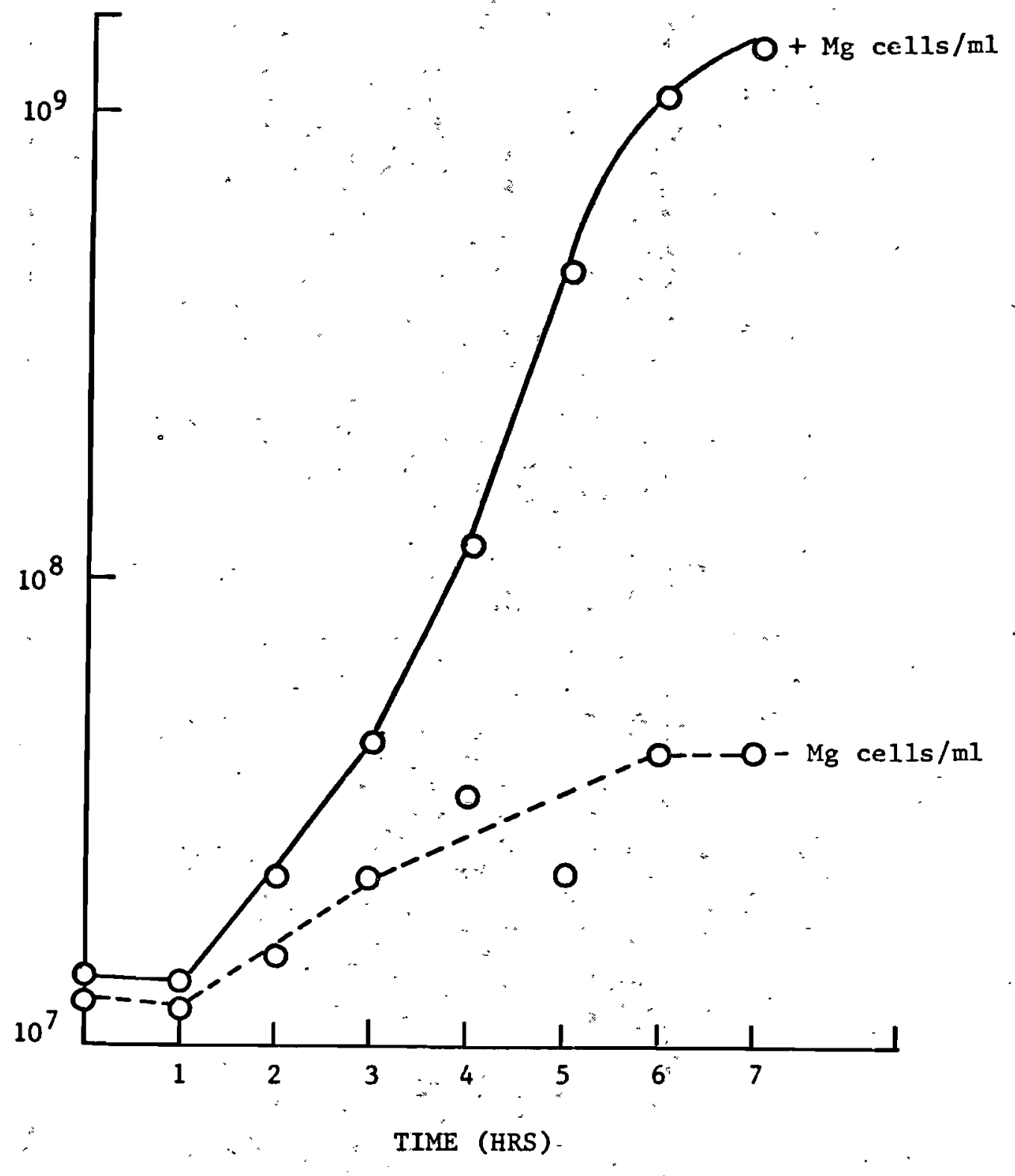

Figure 1. Viable count of Pseudomonas aeruginosa strain $1 \mathrm{C}$ in complete $F$ Medium $(0-0)$ and F Medium magnesium free (0-- - 0 ). 
BACTERIOPHAGE $7 S$ PRODUCTION IN THE PRESENCE OF

$1 \mathrm{mM}$ CONCENTRATIONS OF DIVALENT CATIONS

\section{Cattons $1 \mathrm{mM}$}

No cations

$\mathrm{Mg}$

$\mathrm{Ca}$

$\mathrm{Mn}$

$\mathrm{Zn}$

Ten $\mathrm{ml}$ aliquots of $\mathrm{F}$ Medium ( $\mathrm{Mg}$ free) each containing $1 \mathrm{mM}$ of a different divalent cation, were Inoculated with Pseudomonas aeruginosa strain 1C starter culture grown approximately 3 hr without magnesfum. After two hr growth under aeration at $37 \mathrm{C}$ pseudomonas cultures $\left(1-2 \times 10^{7}\right.$ cells $\left./ \mathrm{m} 1\right)$ were $1 \mathrm{n}-$ fected with bactertophage 7s, at, a multiplicity of one. After $18 \mathrm{hr}$, cells were lysed with chloroform and centrifuged. Assays for free phage were made. 


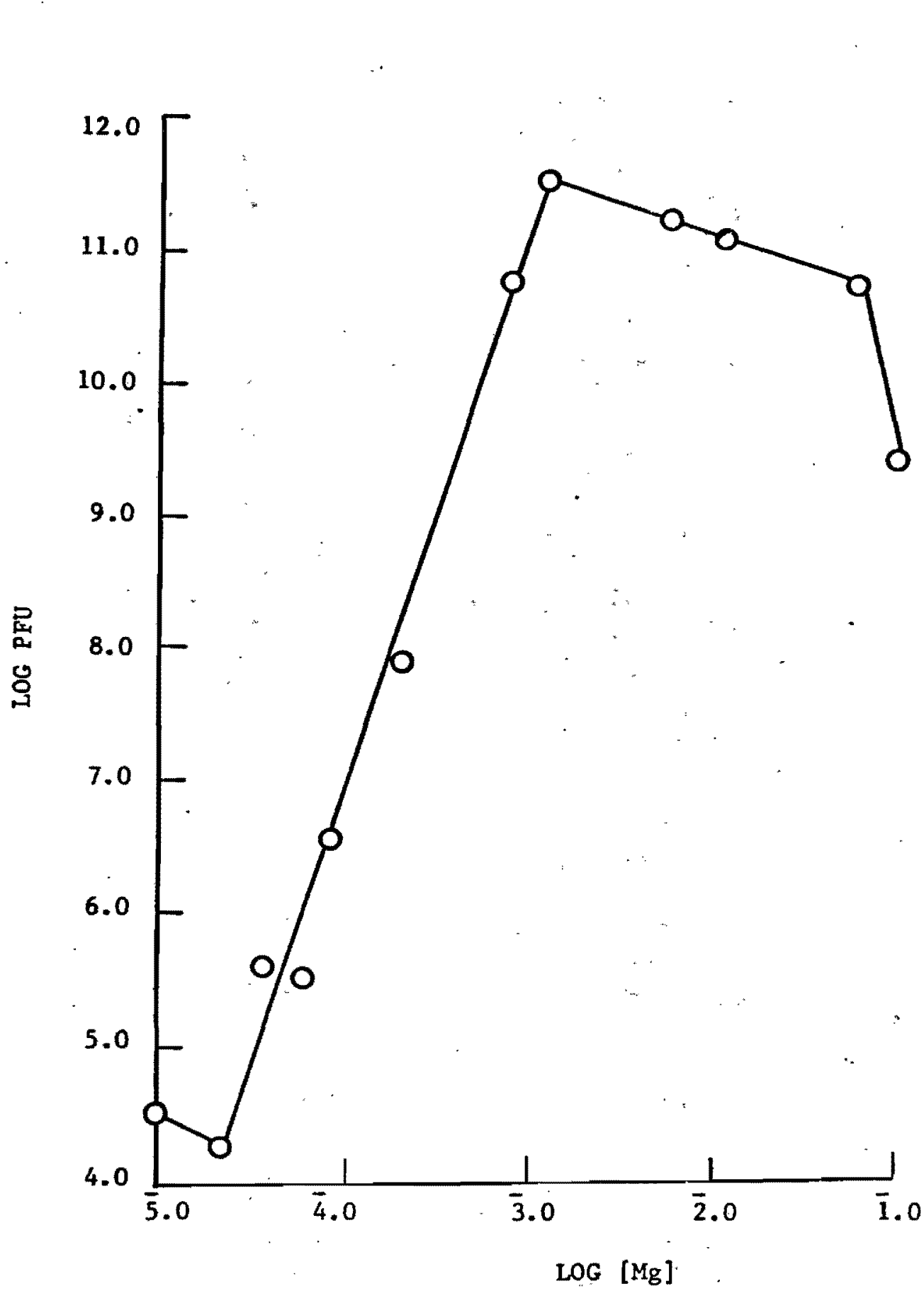

Figure 2. Bacteriophage $7 \mathrm{~s}$ production in the presence of magnesium concentrations. Ten ml aliquots of F Medium (Mg free) each containing a different magnestum concentration, were Inoculated with Pseudomonas aeruginosa starter culture grown in media without magnesium. At $2 \mathrm{hr}$ growth under aeration at $37^{\circ} \mathrm{C}$, Pseudomonas was infected with bacteriophage $7 \mathrm{~s}$, at a multiplicity of $1 .\left(1.7 \times 10^{7} \mathrm{PFU} / \mathrm{ml}\right)$. After $18 \mathrm{hr}$, cells were lysed with chloroform and centrifuged. Assays for free phage were made. 
PRODUCTION OF PHAGE 7s: A SYSTEM CONTAINING $0.1 \mathrm{mM}$ MAGNESIUM AND VARIOUS CONCENTRATIONS

OF A SECOND CATION

No Cation

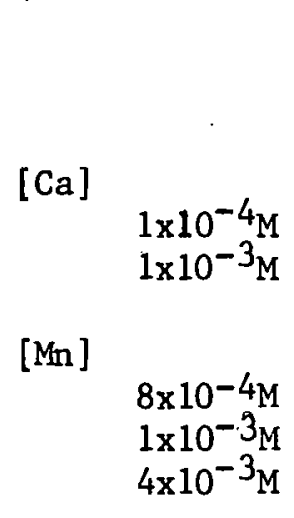

$[\mathfrak{Z n}]$ $1 \times 10^{-3} \mathrm{M}$
[Mg]

$$
1 \times 10^{-3} \mathrm{M}
$$$$
1.2 \times 10^{5}
$$$$
2.8 \times 10^{11}
$$$$
3.7 \times 10^{6}
$$

[Mg ]

$$
\begin{aligned}
& 1 \times 10^{-4} \mathrm{M} \\
& 1 \times 10^{-4} \mathrm{M}
\end{aligned}
$$$$
\text { 2. } 1 \times 10^{10}
$$$$
5.0 \times 10^{9}
$$

[Mg]

$$
\begin{aligned}
& 1 \times 10^{-4} \mathrm{M} \\
& 1 \times 10^{-4} \mathrm{M} \\
& 1 \times 10^{-4} \mathrm{M}
\end{aligned}
$$

$$
4.9 \times 10^{10}
$$$$
1.6 \times 10^{11}
$$$$
2.0 \times 10^{8}
$$

[Mg ]

$$
6.3 \times 10^{6}
$$

Ten $\mathrm{ml}$ aliquots of $\mathrm{F}$ Medium with $0.1 \mathrm{mM}$ magnesium, and with varlous concentrations of a second divalent cation, were inoculated with Pseudomonas aeruginosa starter culture grown without magnesium. At $2 \mathrm{hrs}$ with phage $7 \mathrm{~s}$ at a multiplicity of one $\left(1.7 \times 10^{7} \mathrm{PFU} / \mathrm{m} 1\right)$. After $18 \mathrm{hrs}$, cells were 1 ysed with chloroform and centrifuged. Assays for free phage were made. 
magnesium, $0.1 \mathrm{mM}$, was used because this concentration (as shown in Figure 2) was not sufficient to cause an increase in viral multiplication above the input number of phage $7 \mathrm{~s}$. When the addition of 0.1 mM magnesium was included in appropriate growth fluids of calcium or manganese, an optimum viral titer was reached. The complementation seen in the calcium and manganese cultures appeared not to be due to ionic strength. If the ionic strength were the important factor in phage $7 s$ infection there would have been an additive effect regardless of which combination of ions were used. The zinc-magnesium lysate, Indicated a titer that might have been expected in the presence of only $0.1 \mathrm{mM}$ magnesium.

\section{One Step Growth Curve}

Previous experiments concerning phage $7 \mathrm{~s}$ infection of bacterium Pseudomonas aeruginosa strain $1 \mathrm{C}$ indicated an enhancement of viral titer without a burst (Figure 3) was unexpected. In this study calcium was the only cation used which permitted a significant increase in phage 7s titer. Plaque forming units as assayed from cultures containing manganese showed a small increase which was not sufficient to be considered progeny.

The wide variation of initial phage titer in Figure 3 can not be explained. Each experimental tube contained the same number of bacteria, because the beginning culture was divided into equal aliquots. The variation between phage titer and divalent cation was consistent for several experiments, therefore the variation may be inherent in the phage-divalent cation relationship, or there may be a difference in 


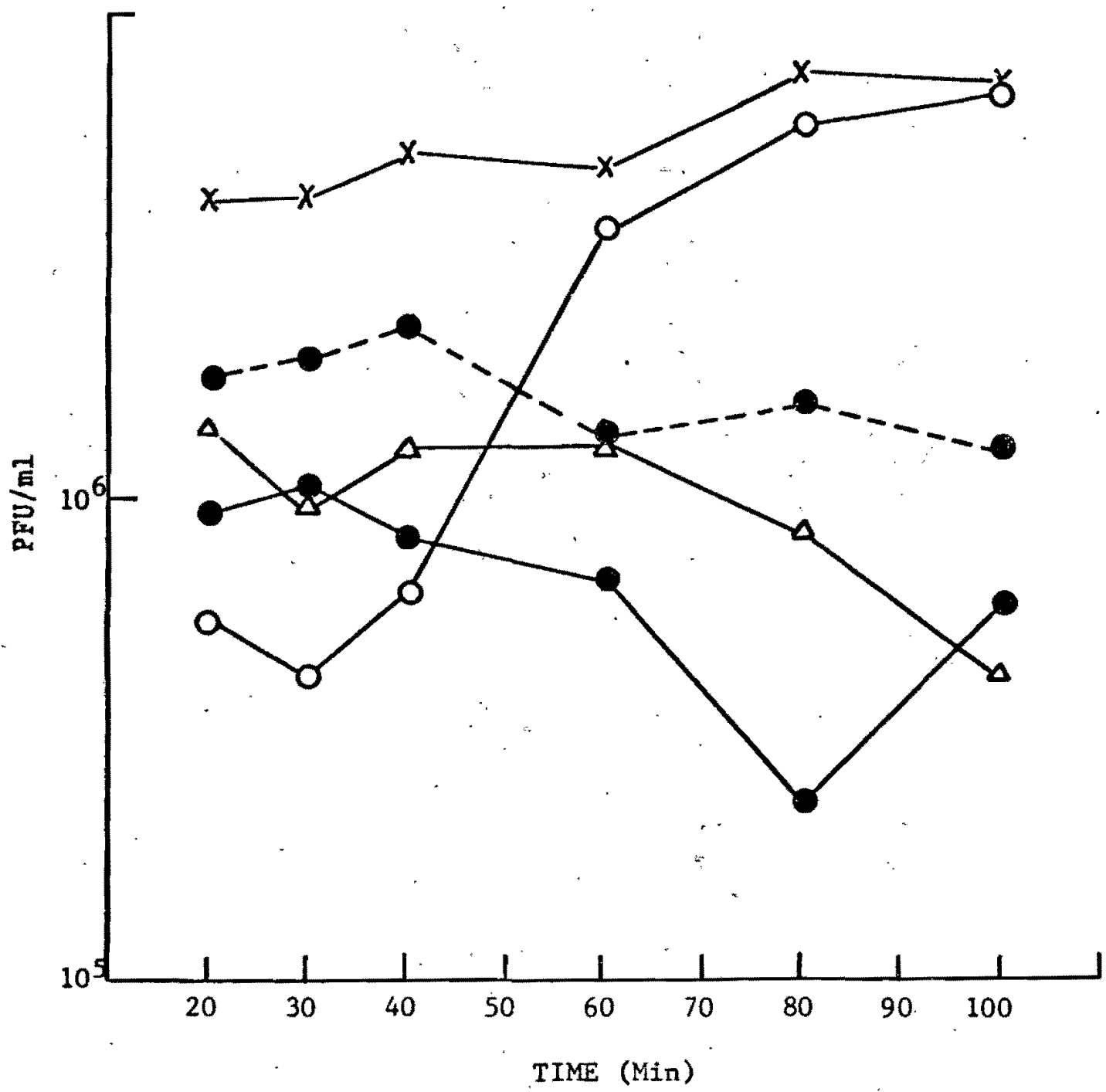

Figure 3. One Step Growth Experiment with Pseudomonas aeruginosa strain IC. Starter cultures were grown in the presence of magnesium. Bacterial cultures were grown to $7 \times 10^{7}$ cells/ml. A 5 minute adsorption interval for phage $7 \mathrm{~s}$ was followed. Infected cells were separated by centrifugation at $4,340 \mathrm{~g}$ for $20 \mathrm{~min}$. A multiplicity of 2 phage particles per cell was used throughout. Divalent ion concentrations were $1 \mathrm{mM}$. F (Mg free), - $-\mathrm{MgSO}_{4},---$; $\mathrm{CaCl}_{2}, 0-0 ; \mathrm{MnSO}_{4}, \mathrm{X}-\mathrm{X}$; $\mathrm{ZnSO}_{4}, \Delta-\Delta$. 
background level with different cations.

In the One Step Growth Experiment, divalent cations were added to appropriate systems at the time of phage $7 \mathrm{~s}$ infection. Divalent cations were added to culture media for $18 \mathrm{hr}$ - phage production studies approximately $2 \mathrm{hr}$ before bacteriophage 7s. infection. Therefore an $18 \mathrm{hr}$ experiment was conducted with the addition of $1 \mathrm{mM}$ concentrations of magnesium and manganese to all preparations at the time of phage infection. Data recorded. in Table.III indicated that the time of addition of magnesium and manganese had little effect on the final titer; so a second One Step Growth Experiment was conducted.

The cells were grown without magnesium for the Figure 4 One Step Growth Curve. There was a loss of titer when the adsorption was conducted in the presence of calcium, magnesium, zinc and in the adsorption complex without a divalent cation. A loss of titer was not observed in the presence of manganese. This condition may be due to phage $7 \mathrm{~s}$ being more stable in the presence of manganese.

An experiment was carried out to determine the stability of free phage in F Medium at $37 \mathrm{C}$ (Figure 5). The data indicated that the stability of phage $7 \mathrm{~s}$, in F Medium-with various divalent cations did not account for the results observed according to the One Step Growth Curve Method. During the first hour of incubation at $37 \mathrm{C}$, free phage incubated in the presence of manganese was less stable than that held in the presence of either magnesium or calcium.

Several methods were tried in order to attempt to increase the efficiency of the One Step Growth Curve. Cells were separated from the growth fluids by filtration through a 0.45 , mm millipore filter. Ce11 
PRODUCTION OF PHAGE 7s WITH ADDITION OF $1 \mathrm{mM}$ CATIONS AT INFECTION TIME

1 mM Cation

$[\mathrm{Mg}]$

[Mn]
PFU/m1 @ 18 Hours

$$
\begin{aligned}
& 2.9 \times 10^{10} \\
& 9.0 \times 10^{5}
\end{aligned}
$$

Ten $\mathrm{m} 1$ altquots of $\mathrm{F}$ Medium (Mg free) were inoculated with Pseudomonas aeruginosa strain 1C starter cultures grown without magnesium. At 2 hrs of growth with aeration at $37 \mathrm{C}, 1$ mM magnestum or manganese

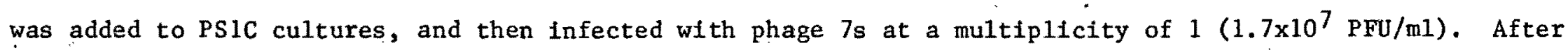
$18 \mathrm{hrs}$, cells were lysed with chloroform and centrifuged. Assays for free phage were made. 


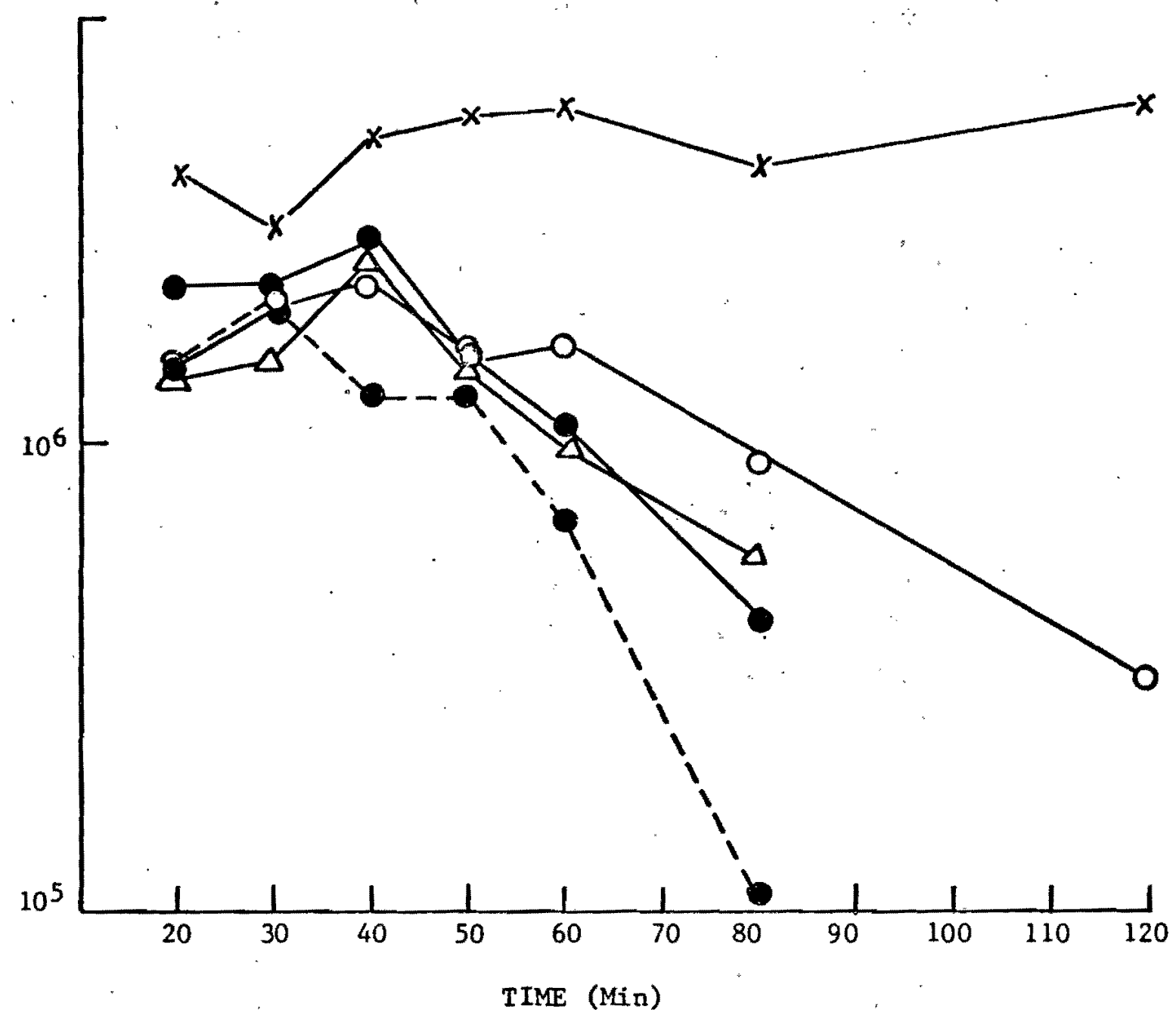

Figure 4. One Step Growth Experiment with Pseudomonas aeruginosa strain 1C. Starter cultures were grown without magnesium. Bacterial cultures were grown to $2.5 \times 10^{7}$ cells/ml. A 5 minute adsorption interval for phage $7 \mathrm{~s}$ was followed. Infected cells were separated by centrifugation at $4,340 \mathrm{~g}$ for $20 \mathrm{~min}$. A multiplicity of 2 phage particles per cell was used throughout. Divalent ion concentrations were $1 \mathrm{mM}$. F (Mg free), $\bullet-\mathrm{MgSO}_{4},---\mathrm{CaCl}_{2}, 0-0 ; \mathrm{MnSO}_{4}, \mathrm{X}-\mathrm{X} ; \mathrm{ZnSO}_{4}, \Delta-\Delta$. 


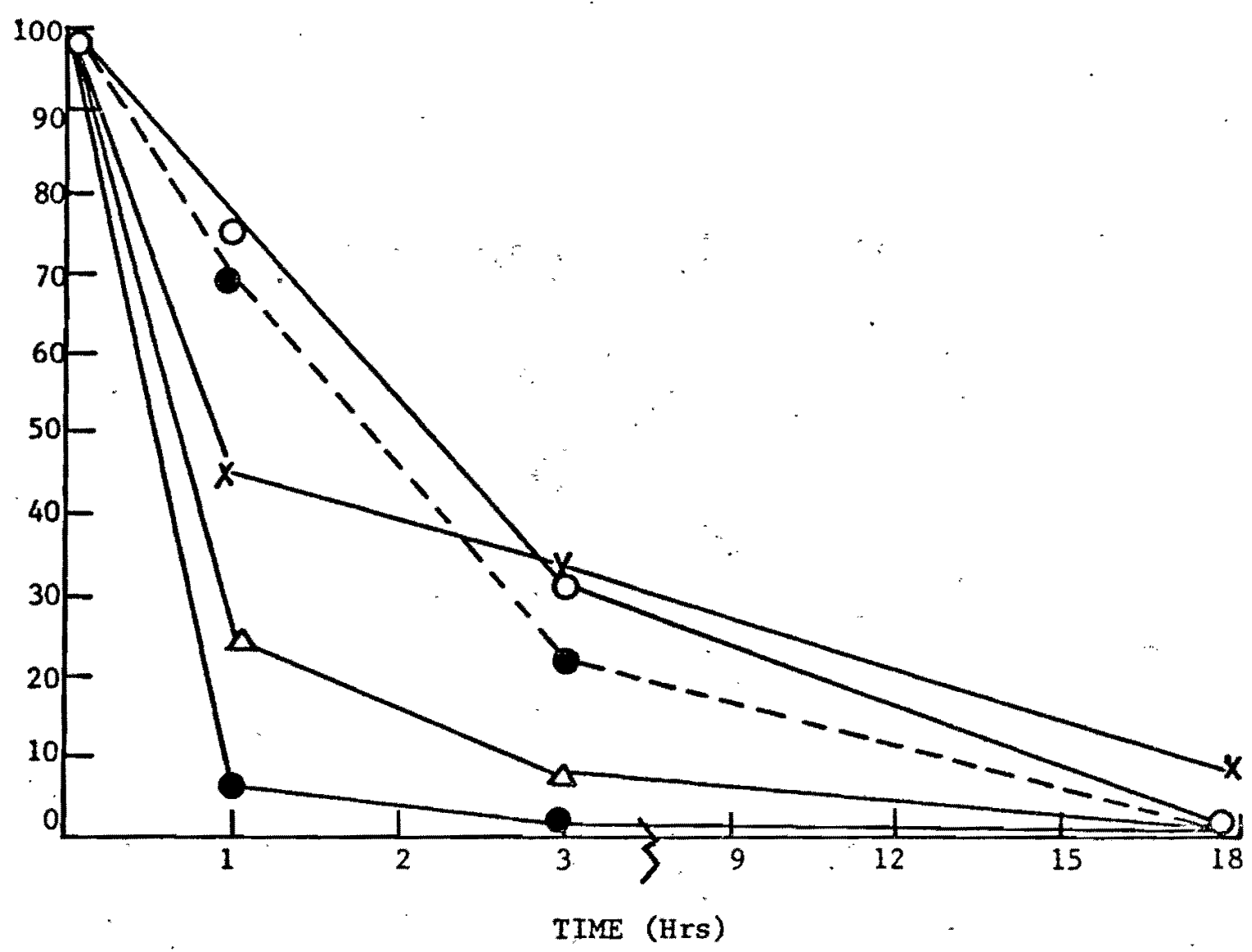

Figure 5. Stabillty of Free Bacteriophage 7s in F Medium Containing Various Concentrations of Divalent Cations. Two ml aliquots of free bacter bacteriophage $7 \mathrm{~s}$ were incubated, in $F$ Medium with $1 \mathrm{mM}$ divalent cations, in a $37^{\circ} \mathrm{C}$ water bath. Assays for free phage were made at varlous time intervals. $\mathrm{F}$ Medtum (Mg free), $-\bullet ; \mathrm{MgSO}_{4}, \bullet-\cdots$; $\mathrm{CaCl}_{2}, 0-0 ; \mathrm{MnSO}_{4}, \mathrm{X}-\mathrm{X} ; \mathrm{ZnSO}_{4}, \Delta-\Delta$. 
numbers, when assayed for viable counts before and after filtration, indicated a cell loss of 50 to $70 \%$.

Infected cells were separated from unadsorbed phage by filtration through a $0.45 \mu \mathrm{m}$ millipore filter. Occasionally, this method gave higher burst sizes than was realized when centrifugation at 4,340 $\mathrm{g}$ was used according to the One Step Growth Curve Experiment. The dilution method for unadsorbed phage separation was used also, and a loss of infected cells was observed, presumably due to reversible attachment.

It was found that the most efficient procedure for this particular system required centrifugation at $3,020 \mathrm{~g}$ for $10 \mathrm{~min}$ although a cell loss of 7 to $10 \%$ was observed consistently. In order for adsorption to follow a first-order reaction an excess of bacteria was required. Therefore to obtain a more efficient One-Step Growth Experiment it was necessary to use larger bacterial cell numbers.

The system used for the final One Step Growth Experiment was one which provided an increase in bacterial cell numbers up to approximately $5 \times 10^{8} \mathrm{cells} / \mathrm{ml}$. For separation of cells from the infected cells, centrifugation at $3,020 \mathrm{~g}$ for $10 \mathrm{~min}$ was used.

Data reported in Figure 6 indicated that magnesium as well as calcium satisfied the divalent cation requirement for infection of $\underline{\text { Pseudomonas }}$ aeruginosa strain $1 \mathrm{C}$ by bacteriophage $7 \mathrm{~s}$ - Calcium gave a significantly larger burst size and therefore appeared to be more efficlent for infection than magnesium. 
Figure 6. One Step Growth Experiment with Pseudomonas aeruginosa strain 1C. The bacterial culture was grown in the presence of magnesium to a concentration of approximately $5 \times 10^{8} \mathrm{cells} / \mathrm{ml}$. Phage $7 \mathrm{~s}$ was adsorbed 5 min at a multiplicity of 0.4 phage particles per cell. Infected cells were separated by centrifugation at $3,020 \mathrm{~g}$ for $10 \mathrm{~min}$. Divalent ion concentration was $1 \mathrm{mM}$. NBYE, $\mathrm{x--1--x;} \mathrm{F} \mathrm{Medium} \mathrm{(Mg} \mathrm{free),}$ $\bullet \mathrm{MgSO}_{4}, \bullet-\cdots-\bullet \mathrm{CaCl}_{2}, 0-0 ; \mathrm{MnSO}_{4}, \mathrm{x} \longrightarrow \mathrm{-}$ 


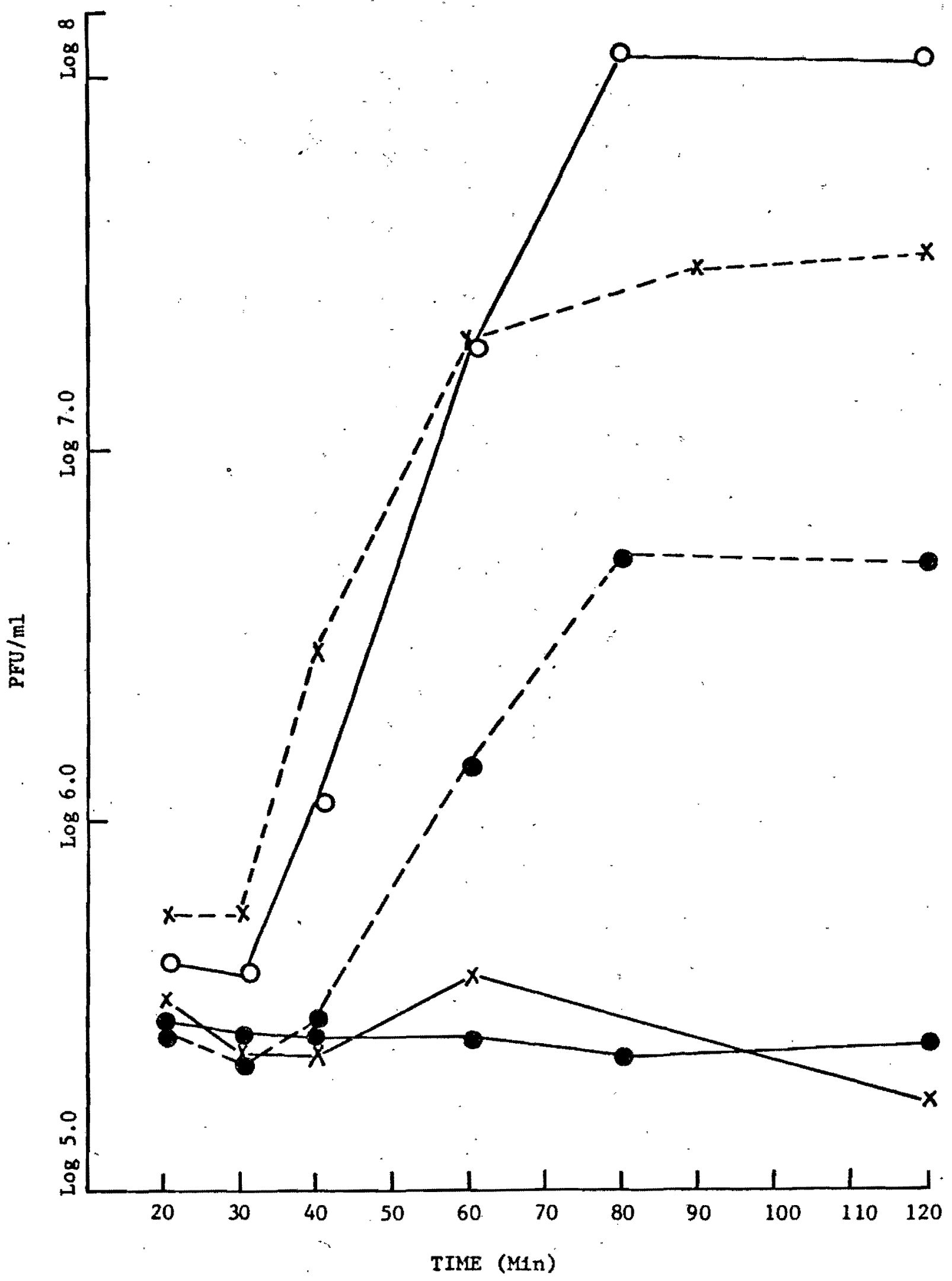




\section{DISCUSSION}

RNA bacteriophage 7s was shown by Feary, Fisher and Fisher to be a unique entity which deserved further characterization. A determination of nutritional requirements of the bacteriophage 7 s infected Pseudomonas aeruginosa strain $1 \mathrm{C}$ system was needed in order to undertake future studies with this system. Therefore, as the topic of this thesis an investigation of divalent cation requirements was undertaken.

Pseudomonas aeruginosa strain 1C, used for the bacteriophage progeny studies, was grown in the absence of magnesium. Cells were grown in a magnesium free medium in order to eliminate interference by magnesium with ions added experimentally. Contrary to expected results, the lack of magnesium in the growth medium introduced uncontrolled variables.

In this system magnesium starvation enhanced cellular autolysis. Eagon (12) showed that pseudomonas cel1 walls contained magnesium. Also, it was observed that pseudomonas magnesium starved cells develop blebs in the cell wall, which made the organism sensitive to 1ysis. Webb (32) showed that rod shaped bacteria required magnesium for cell division. In the absence of magnesium cells elongated without demonstrating formation of a septum. Further effects of magnesium starvation were shown by McCarthy to affect ribosome structure of $\underline{E}$. coli. Ribosomes were degraded in magnesium starved cells; however, there was no apparent loss of viability. Perhaps cellular variables accounted for differences observed rather than effects due to cation requirements.

Under the conditions used, magnesium enhanced progeny production in a range of $8 \times 10^{-4} \mathrm{M}$ to $8 \times 10^{-2} \mathrm{M}$ magnesium ion concentration (Table I, Fig. 2). Progeny were also produced in the presence of magnesiun in 
the One Step Growth Experiment (Fig. 6). The time factor of cation addition before phage $7 \mathrm{~s}$ infection (Table III) had an insignificant effect on progeny production.

Calcium was shown (Table I) to cause a slight enhancement of phage $7 \mathrm{~s}$ production when propagation was carried out in magnesium deficient $\mathrm{F}$ media. The calcium-magnesium combination of cations enhanced phage 7s progeny production (Table II). This was the second Indication that calcium may have been utilized for bacteriophage $7 \mathrm{~s}$ infection.

The final evaluation of calcium enhancement of bacteriophage $7 \mathrm{~s}$ production was shown by the One Step Growth Curve. The use of calcium for the infection of Pseudomonas aeruginosa occurred only if cells were grown in the presence of magnesium.

Manganese did not enhance phage $7 \mathrm{~s}$ production when cells were grown in the presence of magnesium, as shown by the One Step Growth Curve. These results were contrary to progeny production experiments, which were conducted in the presence of both magnesium and manganese. Since bacterial cultures were grown initially in the absence of magnesium, the question of a cell physiological effect is one possibility to account for the high bacteriophage titer (Table II).

Results obtained from the manganese experiment, where a cell physiological effect was suggested, might be explained on the basis of the E. coli magnesium transport system. Silver and Clark (26) showed that manganese was a competitive inhibitor of the magnesium transport system of $\underline{E}$. coli. When extracellular manganese concentration ranged from 2 to $5 \mathrm{mM}$, manganese was taken preferentially into the $\underline{\mathrm{E}}$. coll 
ce11. Intracellular magnesium was displaced by manganese, at which time magnesium was returned to the extracellular environment. Under such conditions manganese was shown to replace ribosomal magnesium.

The use of low cell numbers for viral infection meant there was a low number of sensitive cells available for infection. This correction was made by allowing cells to grow for a longer interval before infection. Since it was difficult to achieve cell counts above $5 \times 10^{8} / \mathrm{ml}$ under the conditions described it may have been advisable to grow cells in a medium which was better suited for the needs of pseudomonads.

Other defects of the system could be linked to the five minute absorption time. Five minutes for absorption was chosen as adequate so that there would be sufficient time to prepare dilutions as well as to plate bacteriophage in each cationic environment before the first burst occurred. A longer absorption period may have been more efficient, in terms of bacteriophage production.

The preceding experiments showed that the RNA bacteriophage 7s required a divalent cation for infection. Either magnesium or calcium could be utilized as long as the cells were grown in a medium containing magnesium. The actual role of magnesium and calcium in the infection process was not shown by these experiments.

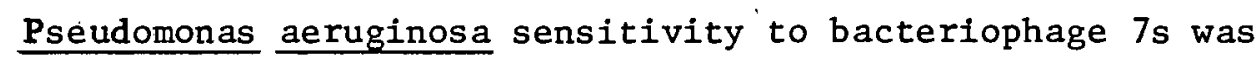
demonstrated $(3,18)$ to be dependent on the presence of polar pili, the adsorption organelle. In addition, in the logarithmic growth phase of Pseudomonas aeruginosa, $64 \%$ of the cells had polar pili, as shown by Weiss (29). Sixty percent of piliated cells had bipolar pili, $25 \%$ of the piliated cells had pili on the flagellated pole and only $15 \%$ had 
pili on the nonflagellated pole. Weiss observed that many cells with bipolar pili contained a partial constriction which appeared to be the formation of a septum. This finding was interpreted as a correlation between pili formation and cell division, in which case each daughter cell contained polar pili.

Weppleman (30) noted that 4 to $8 \%$ of Pseudomonas aeruginosa cells were infected by RNA bacteriophage PP7. The low yield of infected cells were not limited by phage concentration but by the concentration of phage susceptible cells. Weppleman found that sensitivity to phage infection was related to the division cycle. When he infected a culture in logarithmic growth phase all of the sensitive cells had been infected with bacteriophage within $2 \mathrm{~min}$, therefore the remaining cells were resistant to infection. He found that at any one time a small portion of resistant cells became sensitive to infection. Therefore, by infecting cultures with bacteriophage 20 min out of a 25 min division cycle, the remaining uninfected cells had the same division cycle. This was shown as cells which remained uninfected went through several synchroneous divisions. Weppleman hypothesized that the sensitivity to phage PP7 before the division cycle was probably due to newly formed pi11.

The 1ow infectivity seen by Weppleman was demonstrated also in the present study with bacteriophage 7s (Fig. 6). The maximum number of infected cells was approximately $0.12 \%$, but a range of $0.15 \%$ to $3 \%$ infectivity was observed in several experiments.

The latent period of RNA bacteriophage 7s (Fig. 6) in F Media containing calcium was 30 min while in the presence of magnesium it was 
$40 \mathrm{~min}$. When the One Step Growth Curve was conducted in NBYE the latent period was 30 min with a burst size of 60 PFU. The burst size in F medium in the presence of magnesium was 20 while in the presence of calcium the burst size increased to 250 PFU.

In conclusion, the data presented indicates that infection of Pseudomonas aeruginosa by bacteriophage $7 \mathrm{~s}$ is most efficient when conducted in the presence of calcium. 
1. Adams, M. H. "Bacteriophages". Interscience Publishers Second Printing 1966.

2. Argetsinger, J. E. and G. N. Gussin. J. Mo1. Biol. 21:421 (66). Intact Ribonucleic Acid from Defective Particles of Bacteriophage.

3. Bradley, D. E. J. Gen. Microbio1. 45:83 (66). The Structure and Infective Process of a Pseudomonas aeruginosa Bacteriophage Containing Ribonucleic Acid.

4. Bradley, D. E. Genet. Res. Camb. 19:39 (72). A Study of Pili on Pseudomonas aeruginosa.

5. Bradley, D. E. Biochem. and Biophys. Res. Comm. 47:142 (72). Evidence for the Retraction of Pseudomonas aeruginosa RNA Phage Pili.

6. Bradley, D. E. Biochem. and Biophys. Res. Comm. 47:1080 (72). Stimulation of Pilus Formation in Pseudomonas aeruginosa by RNA Bacteriophage Adsorption.

7. Brinton, C. C., Jr. Trans. N. Y. Acad. Sci. 27:1003 (65). The Structure, Function, Synthesis and Genetic Control of Bacterial Pili and a Molecular Model for DNA and RNA Transport in Gram Negative Bacteria.

8. Brinton, C. C., Jr., P. Gemski, Jr., and J. Carnahan. A New Type of Bacterial Pilus Genetically Controlled by the Fertility Factor of E. coli $\mathrm{K} 12$ and its Role in Chromosome Transfer.

9. Crawford, E. M. and R. F. Gesteland. Vir. 22:165 (64). The Adsorption of Bacteriophage R17.

10. Danziger, R. E. and W. Paranchych. Vir. 40:554 (70). Stages in Phage R17 Infection: III. Energy Requirements for the F-Pili Mediated Eclipse of Viral Infectivity.

11. Danziger, R. E. and W. Paranchych. Vir. 40:547 (70). Stages in Phage R17 Infection: II. Ionic Requirements for Phage R17 Attachment to F-Pili.

12. Eagon, R. G., G. P. Simmons and K. J. Carson. Canadian J. Microbiol. 11:1041 (65). Evidence for Presence of Ash and Divalent Metals in the Cell Wall of Pseudomonas aeruginosa.

13. Feary, T. W., E. Fisher, Jr., and T. N. Fisher. Biochem. Biophys. Res. Comm. 10:359 (63). A Small RNA Containing Pseudomonas aerugirosa Bacteriophage. 
14. Feary, T. W., E. Fisher, Jr., and T. N. Fisher. J. Bac. 87:196 (64). Isolation and Preliminary Characteristics of Three Bacteriophages associated. with a Lysogenic Strain of Pseudomonas aeruginosa.

15. Fowler, C. B. and S. S. Cohen. J. Exp. Med. 87:259 (47). Chemical Studies in Host-Virus Interactions: IV. A Method of Determining Nutritional Requirements for Bacterial Virus Multiplication.

16. Krahn, P. M., R. J. O'Callaghan and W. Paranchych. Vir. 47:628 (72). Stages in Phage R17 Infection: VI. Injection of a Protein and RNA into the Host Cell.

17. Lark, K. G. and M. H. Adams. Cold Spring Harbor Quantitative Biology 18:171 (53).

18. Lin, L. and J. Schmitt. Arch. Mikrobio1. 83:120 (72). Adsorption of a Ribonucleic Acid Bacteriophage of Pseudomonas aeruginosa.

19. Loeb, T. and N. D. Zinder. PNAS 47:282 (61). A Bacteriophage Containing RNA.

20. Mande1, M. and A. Higa. J. Mol. Biol. 53:159 (70). Calciumdependent Bacteriophage DNA Infection.

21. Marvin, D. A. and B. Hohn. Bac. Review 33:172 (69). Filamentous Bacterial Viruses.

22. Paranchych, W. Vir. 28:90 (66). Stages in Phage R17

Infection: The Role of Divalent Cations:

23. Paranchych, W., P. M. Krahn, and R. D. Bradley. Vir. 41:465 (70). Stages in Phage R17 Infection.

24. Paranchych, W., S. K. Ainsworth, A. J. Dick and P. M. Krahn. Vir. 45:615 (71). Stages in Phage R17 Infection: V. Phage Eclipse and the Role of F Pili.

25. Puck, T. T., A. Garen and J. Cline. J. Exp. Med. 93:65 (51). The Mechanism of Virus Attachment to Host Cells: I. Role of Ions in the Primary Reaction.

26. Silver, S. and D. Clark. J. Bio. Chem. 246:569 (70). Magnesium Transport in E. coli.

27. Silverman, P. M. and R. C. Valentine. J. Gen. Vir. 4:111 (69). The RNA Injection Step of Bacteriophage f2 Infection. 
28. Valentine, R. C, and H. Wede1. Biochem. and Biophys. Res. Comm. 21:108 (65). The Extracellular Stage of RNA Bacteriophage Infection.

29. Weiss, R. L. J. Gen. Mic. 67: 35 (71). The Structure and Occurrence of $\mathrm{P} i 1 i$ on Pseudomonas aeruginosa.

30. Weppelman, R. M. and C. C. Brinton, Jr. Vir. 44:1 (71). The Infection of Pseudomonas aeruginosa by RNA Pilus Phage PP7: The adsorption Organelle and the Relationship between Phage Sensitivity and the Division Cycle.

31. McCarthy, B. J. Biochim. et Biophy. Acta 55:880 (1962). The Effects of Magnesium Starvation on the Ribosome Content of E. col1.

32. Webb, M. J. Gen. Mic 3:410 (1949). The Influence of Magnesium on Cel1 Division. 2. The Effect of Magnesium on the Growth and Cell Divison of Various Bacterial Species in Complex Media. 